\title{
The Relationship Between the Application of E-Modules Based on Mangrove Forest Ecotourism on The Peace-Loving Character of Students
}

\author{
Asrial ${ }^{*}$, Syahrial ${ }^{2}$, Dwi Agus Kurniawan ${ }^{3}$, Muhammad Dewa Zulkhi ${ }^{4}$ D \\ 1,2,3,4 Jambi University, Jambi, Indonesia \\ e-mail:porigih@gmail.com
}

\section{A R T I C L E I N F O}

Article history:

Received April 25, 2021

Revised April 27, 2021

Accepted June 17, 2021

Available online August 25, 2021

\begin{tabular}{l}
\hline Kata Kunci: \\
E-Module, Cinta Damai, \\
Kearifan Lokal
\end{tabular}

Keywords:

Peace Love, Local Wisdom, E-

Module

DOI:

https://dx.doi.org/10.23887/jet.v5 i3.34043

\section{A B S T R A C T}

Teachers still find it difficult to use technology to develop open materials for students, so that it has an impact on low student learning outcomes. The purpose of this study was to analyze the peace-loving character of students after an electronic module based on local wisdom ecotourism of The Basal Babu Mangrove Forest was applied. This type of research is quantitative with research methods using quantitative associative research. The sample in this study was 32 fourth-grade elementary school students. The sampling technique was total sampling. The techniques used to collect data are observation, interviews, and questionnaires. The data collection instrument used was a questionnaire. The data analysis technique used descriptive statistics and inferential statistics. The result in this study is that the cinta damai character owned by the students has a good category, seen from the peace-loving character after the electronic module based on local wisdom, using the correlation results obtained 0.937 and the results of a positive relationship. This shows that there is a relationship between the peaceloving character and the application of the electronics module. This research implies that the application of this electronic module helps students learn independently and can improve students' character.

This is an open access article under the CC BY-SA license.

Copyright (C) 2021 by Author. Published by Universitas Pendidikan Ganesha.

\begin{abstract}
A B S T R A K bagi siswa, sehingga berdampak pada hasil belajar siswa yang rendah. Tujuan

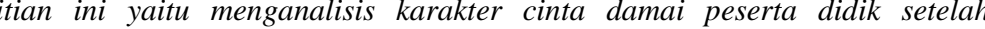
diterapkan modul elektronik berbasis kearifan lokal ekowisata hutan bakau Pangkal penelitian kuantitatif asosiatif. Sampel dalam penelitian ini adalah 32 siswa kelas IV SD. Teknik pengambilan sampel adalah total sampling. Teknik yang digunakan pengumpulampulkan data yaitu observasi, wawancara, dan kuesioner. Instrumen menggunakan statistik deskriptif dan statistik inferensial. Hasil dalam penelitian ini adalah karakter cinta damai yang dimiliki siswa memiliki kategori baik, dilihat dari karakter cinta damai setelah menggunakan modul elektronik berbasis kearifan lokal, diperkuat dengan hasil korelasi yang diperoleh sebesar 0,937 dan
menghasilkan hubungan yang positif. Hal ini menunjukan bahwa terdapat hubungan antara karakter cinta damai dan penerapan modul elektronik. Implikasi penelitian ini yaitu penerapan modul elektronik ini membantu siswa belajar secara mandiri dan dapat meningkatkan karakter siswa.
\end{abstract}


technology to facilitate learning (Astra et al., 2020; Cloonan et al., 2020). The utilization of technology is needed to improve learning for more advanced education. Technology that can facilitate the learning process will continue to be needed to advance the world of education (Hamid et al., 2021; Jang et al., 2021).

The problem that occurs today is that many teachers have not been able to utilize this technology very well (Qumillaila et al., 2017; Sri Sulistiyawati, 2018). Teachers still find it difficult to use technology to develop learning media for students (Divayana, 2017; Manurung \& Panggabean, 2020). This technology can be used in developing learning media for students. This problem was also found in one elementary school. Based on the results of observations and interviews that have been carried out, it was found that teachers had difficulties in developing learning media or technology-based teaching materials. In addition, learning is only conventional, so students feel less interested in learning. Previous research also revealed that if students feel bored or not interested in learning, it will impact low student learning outcomes (Ali et al., 2021; Prastika et al., 2021; Soleimani et al., 2014). Based on these problems, it causes students to feel uncomfortable in learning and causes low student learning outcomes. Learning with values needs to be integrated using good media and methods and requires creative teachers (Boesdorfer, 2019; Gil-Flores et al., 2017). As a teacher conveying information in learning is required to convey information as best as possible, the teacher makes it possible to operate technology. Many teachers who have not been able to operate technology have not used electronic modules in learning with several obstacles, namely on facilities, infrastructure, and networks (Handayani et al., 2021; Resita \& Ertikanto, 2018). One of them is social studies learning which still uses print media, especially on materials related to local wisdom that teachers rarely explain.

One of the supports for learning effectiveness in education is the availability of teaching materials in schools. The connection between the environment and adequate teaching materials will make learning more meaningful (Liu et al., 2021; Mastroleo et al., 2020). Good teaching materials are teaching materials that can help students understand the content of the material. One of the technology-based teaching materials is Emodule. Learning using effective E-modules can change students' perceptions of scientific concepts, and their learning outcomes are optimally supported by guidance on learning activities which are also equipped with evaluation resources (Alias \& Siraj, 2012; Aprilia \& Suryadarma, 2020). E-module is one of the technologies in education that raises students' enthusiasm in the learning process. Electronic modules provide learning, understanding, and curiosity to students, and their use makes it easier to carry out learning activities (Cloonan et al., 2020; Lee \& Osman, 2012). The learning process using electronic modules must be of good quality. Learning does not deviate and has good quality. That is why the importance of E-modules for students in schools. E-modules used in the learning process will foster creativity, productive thinking habits, create learning conditions that are active, effective, innovative, and fun (Irwansyah et al., 2017; Mastroleo et al., 2020).

Electronic modules can encourage the younger generation to take learning resources from no longer teacher-centered, like using technology. The benefits of using e-modules as teaching materials can make it easier for teachers to introduce, teach, and instill concepts to students (Astra et al., 2020; Susanti et al., 2020). The Emodule that will be developed is based on character education. Character education is one of the efforts made in the educational process to shape individual attitudes and morals. The importance of planting character must be instilled in students (Muhamad Nova, 2017; Singh, 2019). E-module material with local wisdom as a source of learning, the many values contained, and an effort to maintain a culture in Indonesia. It is very well used as subject matter in school. The local wisdom is inherited, namely the peace-loving character. Peace-loving is words, deeds, attitudes, and actions that cause others to feel happy and at ease with their presence. Therefore, the cultivation of attitudes or character in students is very necessary. Many characters can be integrated into learning, one of which is the peace-loving character associated with learning materials using the Electronic Module.

Previous research stated that E-modules could facilitate students 'learning (Tchen et al., 2018; Triwahyuningtyas et al., 2020). Other research findings also state that E-modules can attract students' attention to learning to become fun (Aprilia \& Suryadarma, 2020; Rasmussen et al., 2020). The development of this Emodule uses the theory of developing teaching materials to make it easier for students to understand the material presented. The difference between this study and other studies is that this study examines the relationship between electronic modules and peace-loving characters, while other studies research development. This study aims to analyze students' peace-loving character after applying an electronic module based on local wisdom Ecotourism in the Basal Babu Mangrove Forest. It is hoped that this E-module can help students in learning.

\section{METHOD}

This research is quantitative; quantitative research contains or relates to the numbers on the type of data. This research uses an associative approach, which is a related study. Research instruments using questionnaires, interviews, and interviews are questions and answers between information seekers and sources who understand a good thing with little or little data collection techniques (Sugiyono, 2018). The questionnaire 
was used in student response questionnaires and indicators of peace love, with a valid number of questions, 16 points. Reliability is calculated using the Cronbach alpha formula. After the instrument is tested and analyzed, reliability obtained reliability coefficient of manners of 0.680 and to help each other by 0.610 so that it can be concluded that the instrument is reliable. The form of a questionnaire used is a closed questionnaire that is on each question or statement has been provided several answers options for respondents to choose by using the category Likert five assessment scale, as for the grid of the two handles is as follows.

Table 1. Student Response Questionnaire Grid

\begin{tabular}{cllc}
\hline No. & Assessment Aspects & \multicolumn{1}{c}{ Statement } & Number of Items \\
\hline 1 & Material & The material is the same as the existing learning. & 4 \\
2 & Module contents & Structured module content & 3 \\
3 & Module view & Interesting module view & 4 \\
4 & Module language & Easy to understand & 5 \\
& & Provide clear information & 4 \\
\hline
\end{tabular}

Table 2. Peace-loving Character Grille

\begin{tabular}{cccc}
\hline No. & Assessment Aspects & Statement & Number of Items \\
\hline 1 & Take care of the & Not damaging things around & 4 \\
& environment & & 4 \\
2 & Respect each other & Respecting the opinions of others & 4 \\
3 & Greeting each other & Greeting teachers and friends everywhere. & 5 \\
4 & Help each other & Helping a friend in distress & 4 \\
\hline
\end{tabular}

The population in this study is the number of all students of grade IV SD Negeri 45 /I Sridadi. The sample used was all students of class IVwhich amounted to 32 people. In the determination of samples used sampling techniques, total sampling, whose sample determination technique is taken from the number of populations (Sugiyono, 2018). The reason researchers used total sampling was that the number of populations was less than 100 .

Validation of electronic modules is the validation of several experts, namely linguists, material experts, media experts, and practitioners. The four experts filled out validation sheets sourced on the results of modifications from BSNP 2016 sources. Instrument Assessment of the validity of local wisdom-based electronic modules is arranged using a Likert scale with a positive statement. Data from the results of the responses of several experts is analyzed in the following two steps, namely first summing the total score of each expert for all indicators and secondly giving validity values using the means, the number of scores obtained divided by the maximum score is then multiplied by $100 \%$. Analysis of the validity of modules is done using descriptive statistics whose results are illustrated through graphs. The validation score becomes a value with a range of 0 100. The results obtained are then interpreted with the following criteria:

Table 3. Modified Likert Scale Electronic Module Validation Criteria

\begin{tabular}{cc}
\hline Percentage & Criterion \\
\hline $0-20$ & Unworthy \\
$21-40$ & Less worthy \\
$41-60$ & Decent enough \\
$61-80$ & proper \\
$81-100$ & Very worthy \\
\hline
\end{tabular}

The data analysis in this study uses descriptive statistics and inferential statistics. Descriptive statistics are used to analyze data by describing or describing the collected data as it is, without intending to make broad conclusions or generalizations (Sugiyono, 2018). The study used maximum, minimum, and mean values. Inferential statistics are statistics used to analyze sample data, and the results will be generalized or inferred to the population from the origin of the sample it was taken. 


\section{RESULT AND DISCUSSION}

\section{Result}

The practical aspect is the relationship between indicators and characters implanted through implementing an electronic module based on the local wisdom of Pangkalan Babu mangrove ecotourism. The results of this data were obtained from the distribution of research questionnaires on student attitudes towards the relationship between indicators and peace-loving characters carried out on 32 students of SD Negeri 45/I Sridadi. Data on student attitudes in this study were obtained based on a questionnaire (questionnaire) in a checklist, totaling 17 statements. The Attitude Scale is used to test students' attitudes towards certain objects. The results of the attitude categories include: rejecting (negative), supporting (positive), and neutral. The results of the attitude questionnaire data shown in the following data analysis include two parts of the assessment. The first is a timelapse assessment with the following attitude categories: very bad, not good, enough, good, very good. The attitude category assessment is based on the frequency and percentage of all students choosing each category. The second scale is based on the attitude scale. The attitude scale used is a Likert scale consisting of 5 different scores.

Assessment is based on the number of students who choose each attitude scale and find the mean, maximum, and minimum. The two attitude assessments were obtained by descriptive statistical analysis using SPSS 17 data processing software. The peaceful, comfortable, and harmonious atmosphere at school: $6.25 \%$ bad character category ( 2 out of 32 students), $6.25 \%$ poor student ( 2 out of 32 students), 9,375\% moderate category student (3 out of 32 students), students with good categories were $46.875 \%$ (15 of 32 students), and students with very good attitudes were $31.25 \%$ ( 10 of 32 students). Obtained is an average value of 76.75 , a maximum of 84 , and a minimum of 59 . These results indicate that students' attitudes towards creating a harmonious, peaceful, and comfortable classroom and school atmosphere show a positive attitude seen from the results of data analysis that $46.875 \%$ of students or 15 of them a total of 32 students in the good category. This is also supported by the average result of 76.75, which is included in the good category. Related to the first indicator of love of peace, creating a harmonious, peaceful, and comfortable classroom and school atmosphere is reinforced by the results of interviews with several sample questions as follows.

"Apologizing when you make a mistake?"

"I will immediately apologize when a friend is disturbed by my actions."

"What do you do so that the classroom atmosphere is always safe and peaceful?"

"I'm not going to make a fuss in class"

The results of descriptive statistical data analysis of the second peace-loving indicator using e-modules through the SPSS application. The results of the peace-loving character based on habits are the very bad character category of $3.125 \%$ ( 1 of 32 students), $6.25 \%$ of students with bad category ( 2 of 32 students), students with good category as much as $9.375 \%$ (3 of 32 students ), students with good category were $3.75 \%$ (12 out of 32 students), and students with very good attitude were $43.75 \%$ (14 out of 32 students). Meanwhile, based on the attitude scale, the data results above show that the data obtained are an average value of 80.15 , a maximum of 90 , and a minimum of 62 . These results indicate that students' attitudes towards non-violent behavior of school residents show a positive judging attitude. They were based on the results of data analysis that $43.75 \%$ of students or 14 of the total 32 students in the very good category. It is also supported by the average result of 80.5 , which is included in the good category. Regarding the indicators of love of peace in creating a harmonious, peaceful, and comfortable classroom and school atmosphere, this is reinforced by interviews with some sample questions as follows

"What do you do when your friends fight?"

"I will admonish my friend so that there are no fights and commotions."

"Do you agree that your friend hit his friend?"

"I don't agree, because it hurts that it will cause division."

Based on the results of data analysis, it can be explained that the table above shows the results of Student Responses to the Electronic Module: the category of students' character is very bad as much as $3.125 \%$ (1 of 32 students), students with bad categories as much as $6.25 \%$ (2 of 32 students) students with enough category as many as $21.875 \%$ ( 7 out of 32 students), students with good category as many as $31.25 \%$ (10 out of 32 students), and students with very good attitude as many as $28.125 \%$ (9 out of 32 students). Meanwhile, the attitude scale from the data above shows that the data obtained is an average value of 82.00 , a maximum of 91 , and a minimum of 62. These results indicate attitudes. Student responses to the Electronic Module show a positive attitude as seen from the results of data analysis that $31.25 \%$ students or 10 of the total 32 students in the good category. This is also supported by the average result of 82.0 , which is included in the good category. Regarding Student Responses to E-Module, it is strengthened by the results of interviews with several examples of questions as follows. 
"How does it feel to learn to use electronic modules?"

"I'm happy to see such an interesting picture."

"Do you agree if you learn to use the E Module?"

"I agree, because it's fun and not boring."

The results of the assumption of normality and linearity in the character response data of social care students using SPSS 17 are in the table above, the value of sig >0.05. The normality value of 0.228 in the sig normality value means that the existing data is normal because the sig value is $>0.05$. From the table above, it can be seen that the significant values resulted from the linearity test. From the data above, the value of sig > 0.05 , the data is said to be linear. The sig linearity value of 0.145 means that the existing data is linear because the sig value is $>0.05$. The relationship between the two indicators of peace-loving characters, such as creating a harmonious, peaceful, and comfortable classroom and school atmosphere and Familiarizing the behavior of antiviolent school residents, is 0.937 . The relationship between the two indicators is strong, with a sig value of 0.000 less than 0.005 , it can be concluded that there is a relationship between indicators creating an atmosphere harmonious, peaceful, and comfortable classrooms and schools as well as indicators and intimacy of behavior of school residents who are anti-violent towards electronic modules with an R-value of 0.937 and positive. If the value of $\operatorname{sig}<0.05$, then there is a relationship between the two variables.

\section{Discussion}

Several material experts and media experts have validated the application of an electronic module based on local wisdom of Pangkal Babu Mangrove Forest Ecotourism, with the results obtained 61-80\% in the appropriate category. Therefore, the electronic module based on local wisdom of local ecotourism in the Pangkal Babu Mangrove Forest can be applied in learning as teaching materials and shape Cinta Damai's character in students. This is because the value of local wisdom in the module discusses traditions that not everyone has. This is what makes the character of Cinta Damai students formed by accepting and always doing good to the environment around us.

These two indicators of peace-loving character can be seen from implementing electronic modules based on local wisdom. When implementing the electronic module based on local wisdom, the mangrove babu ecotourism base responded to the electronic module. The responses came from several experts, namely linguists, materials, media, and practitioners, with a score of $61-80 \%$ in the appropriate category. From the data obtained, it was concluded that the electronic module technically got a good category so that the electronic module was judged from the language, media, material, and practitioners worthy of being used as a learning resource in a lesson. A good learning module is easily understood by students (Boyd, 2019; Syahroni et al., 2016). Some summaries of impressions and suggestions from respondents related to the use of electronic modules, namely learning using electronic modules is very fun, interesting, and students prefer learning to use electronic modules rather than studying books, encouraging students to learn, student character can be formed according to the material in the electronic module. Previous research has also stated that using electronic modules will make students feel comfortable and fun in learning, affecting student learning outcomes (Hamdunah et al., 2016; Seruni et al., 2020).

The application of electronic modules to students gave a very enthusiastic response because they found something new from previous lessons and provided new experiences for them. Interesting modules will provide students with a learning experience (Handayani et al., 2021; Neppala et al., 2018). In the application of this Emodule, the response given by the students is very high, such as curiosity or strong curiosity, enthusiasm in learning, and more focus on what is conveyed in the E-module. Implementation of an electronic module based on local wisdom Mangrove Forest Ecotourism in the base of the babu towards the peace-loving character of students in elementary schools, as one of character education applications. Character education is very important in education, especially in elementary schools, because the personality of students who are instilled from an early age is more emphasized and is expected to be the main foundation in building Indonesian people who are pious and ready to compete in the future (Kurniawan, 2018; Maunah, 2015; Rosikum, 2018).

Character education in elementary schools has eighteen-character messages: religion, discipline, hard work, honesty, tolerance, independence, independence, curiosity, democracy, national spirit, friendly/communicative, appreciating achievement, love for the homeland, and love for peace. One of them is a peace-loving character, and the peace-loving character is an action that makes others feel safe and happy in their presence. Students with peace-loving characters respect others, promote harmony, avoid conflict and violence, and tolerance toleransi (Asriani et al., 2017; Palunga \& Marzuki, 2017). Peace-loving characters have indicators of creating a harmonious, peaceful, and comfortable classroom and school atmosphere, getting used to nonviolence, getting used to the behavior of school residents who are not gendered biased, the behavior of all compassionate school members. 
This study, utilizing the local wisdom of Pangkalan Babu mangrove ecotourism into learning to instill peace-loving character values in learning using electronic modules. The findings of previous studies stated that E-modules could improve student learning outcomes (Kimianti \& Prasetyo, 2019; Sadimin Sadimin et al., 2017). The findings of previous studies also state that the module can increase a pleasant learning atmosphere (Hamdunah et al., 2016; Linda et al., 2018). It can be concluded that E-module can help students in learning. The novelty of this study lies in the variables studied. The first indicator of the peace-loving character is creating a harmonious, peaceful, and comfortable classroom and school atmosphere in and secondly, getting used to the behavior of school residents who are anti-violent. The two indicators are seen after applying the electronic module in this study to see the connection between the application of the electronic module and the peace-loving character indicator.

The research implications of developing an electronic module based on Pangkal Babu Mangrove Ecotourism class IV Theme 3 and Subtheme 3 using the 3D Pageflip Professional application can be teaching materials in learning for students to know the diversity of local wisdom in the local province, Jambi Province, to be precise. Besides being a teaching material that suits the needs of students and can be used as a source of independent learning. The limitation of this research is that this electronics module is limited to the basic competencies of class IV theme 3 Care for Living Creatures theme 3 Let's Love the Learning Environment 1 based on local wisdom of Ekowiswata Manggrove Pangkal Babu. The impact for students is the formation of peace-loving characters through electronic modules with the culture around them. The recommendation of this research is to apply an electronic module based on the local wisdom of Pangkalan Babu mangrove ecotourism that can be applied with the character of environmental care, social care, and responsibility.

\section{CONCLUSION}

Application of Electronic Module Based on Local Wisdom Ecotourism in Pangkal Babu Mangrove Forest has a close relationship with the application of the Love of Peace character and affects students' character. Student responses to the Local Wisdom-based electronic module got positive results, and we are in a good category, so implementing the Local Wisdom-based electronic module was feasible. It is recommended for teachers to develop or use this electronic module to help students learn independently.

\section{REFERENCES}

Ali, S., Hafeez, Y., Humayun, M., Jamail, N. S. M., \& Aqib, M. (2021). Enabling Recommendation System Architecture in Virtualized Environment for E-Learning. Egyptian Informatics Journal. https://doi.org/10.1016/j.eij.2021.05.003.

Alias, N., \& Siraj, S. (2012). Effectiveness of Isman Instructional Design Model in Developing Physics Module Based on Learning Style and Appropriate Technology. Procedia - Social and Behavioral Sciences, 64. https://doi.org/10.1016/j.sbspro.2012.11.002.

Almusawi, H. A., Durugbo, C. M., \& Bugawa, A. M. (2021). Innovation in Physical Education: Teachers' Perspectives on Readiness for Wearable Technology Integration. Computers \& Education, 167. https://doi.org/10.1016/j.compedu.2021.104185.

Aprilia, I., \& Suryadarma, I. G. P. (2020). E-Module of Mangrove Ecosystem (EMME): Development, Validation, and Effectiveness in Improving Students' Self-Regulated. Biosfer: Jurnal Pendidikan, 13(1), 114-129. https://doi.org/10.21009/biosferjpb.v13n1.114-129.

Asriani, P., Sa'dijah, C., \& Akbar, S. (2017). Bahan Ajar Berbasis Pendidikan Karakter. Jurnal Pendidikan: Teori, Penelitian, dan Pengembangan, 2(11), 1456-1468. http://dx.doi.org/10.17977/jptpp.v2i11.10160.

Astra, I. M., Raihanati, R., \& Mujayanah, N. (2020). Development of Electronic Module Using Creative Problem-Solving Model Equipped with HOTS Problems on The Kinetic Theory of Gases Material. Jurnal Penelitian \& Pengembangan Pendidikan Fisika, 6(2), 181-194. https://doi.org/10.21009/1.06205.

Baba, J., \& Rostam Affendi, F. (2020). Reading Habit and Students' Attitudes towards Reading: A Study of Students in the Faculty of Education UiTM Puncak Alam. Asian Journal of University Education, 16(1), 109. https://doi.org/10.24191/ajue.v16i1.8988.

Boesdorfer, S. B. (2019). Growing Teachers and Improving Chemistry Learning: How Best Practices in Chemistry Teacher Education Can Enhance Chemistry Education. ACS Symposium Series, 1(1). https://doi.org/10.1021/bk-2019-1335.ch001.

Boyd, L. (2019). Using Technology-Enabled Learning Networks to Drive Module Improvements in the UK Open University. Journal of Interactive Media in Education, 2019(1), 1-7. https://doi.org/10.5334/jime.529.

Chang, H.-Y., Wu, H.-F., Chang, Y.-C., Tseng, Y.-S., \& Wang, Y.-C. (2021). The Effects of a Virtual 
Simulation-Based, Mobile Technology Application on Nursing Students' Learning Achievement and Cognitive Load: Randomized Controlled Trial. International Journal of Nursing Studies, 120. https://doi.org/10.1016/j.ijnurstu.2021.103948.

Chen, C.-H., \& Tsai, C.-C. (2021). In-Service Teachers' Conceptions of Mobile Technology-Integrated Instruction: Tendency towards Student-Centered Learning. Computers \& Education, 170(1). https://doi.org/10.1016/j.compedu.2021.104224.

Chen, Y., Mayall, H. J., York, C. S., \& Smith, T. J. (2019). Parental Perception and English Learners' MobileAssisted Language Learning: An Ethnographic Case Study from a Technology-Based Funds of Knowledge Approach. Learning, Culture and Social Interaction, 22. https://doi.org/10.1016/j.lcsi.2019.100325.

Cloonan, M. R., Cloonan, D. J., Schlitzkus, L. L., \& Fingeret, A. L. (2020). Learners with Experience in Surgical Scrub Benefit from Additional Education with an Interactive E-Learning Module. Journal of the American College of Surgeons, 4(2). https://doi.org/10.1016/j.jamcollsurg.2020.08.521.

Divayana, D. G. H. (2017). Evaluasi Pemanfaatan E-Learning Menggunakan Model CSE-UCLA. Cakrawala Pendidikan, 2. https://doi.org/10.21831/cp.v36i2.12853.

Gil-Flores, J., Rodríguez-Santero, J., \& Torres-Gordillo, J. J. (2017). Factors that Explain the Use of ICT in Secondary-Education Classrooms: The Role of Teacher Characteristics and School Infrastructure. Computers in Human Behavior, 68, 441-449. https://doi.org/10.1016/j.chb.2016.11.057.

Hamdunah, Yunita, A., Zulkardi, \& Muhafzan. (2016). Development a Constructivist Module and Web on Circle and Sphere Material with Wingeom Software. Journal on Mathematics Education, 7(2), 109116. https://doi.org/10.22342/jme.7.2.3536.109-116.

Hamid, S. N. M., Lee, T. T., Taha, H., Rahim, N. A., \& Sharif, A. M. (2021). E-Content Module for Chemistry Massive Open Online Course (MOOC): Development and Students' Perceptions. Journal of Technology and Science Education, 11(1), 67-92. https://doi.org/10.3926/jotse.1074.

Handayani, D., Elvinawati, E., Isnaeni, I., \& Alperi, M. (2021). Development of Guided Discovery Based Electronic Module for Chemical Lessons in Redox Reaction Materials. International Journal of Interactive Mobile Technologies (IJIM), 15(07), 94. https://doi.org/10.3991/ijim.v15i07.21559.

Hendawi, M., \& Nosair, M. R. (2020). Students' Technological Awareness at the College of Education, Qatar University. Cypriot Journal of Educational Sciences, 15(4), 749-765. https://doi.org/10.18844/cjes.v15i4.5057.

Irwansyah, F. S., Lubab, I., Farida, I., \& Ramdhani, M. A. (2017). Designing Interactive Electronic Module in Chemistry Lessons. Journal of Physics: Conference Series, 895(1). https://doi.org/10.1088/17426596/895/1/012009.

Jang, M., Aavakare, M., Nikou, S., \& Kim, S. (2021). The Impact of Literacy on Intention to Use Digital Technology for Learning: A Comparative Study of Korea and Finland. Telecommunications Policy, 45(7). https://doi.org/10.1016/j.telpol.2021.102154.

Kimianti, F., \& Prasetyo, Z. K. (2019). Pengembangan E-Modul IPA Berbasis Problem Based Learning untuk Meningkatkan Literasi Sains Siswa. Kwangsan: Jurnal Teknologi Pendidikan, 7(2), 91. https://doi.org/10.31800/jtp.kw.v7n2.p91--103.

Kurniawan, S. (2018). Globalisasi, Pendidikan Karakter, dan Kearifan Lokal yang Hybrid Islam pada Orang Melayu Kalimantan Barat. Jurnal Penelitian, 12(2). https://doi.org/10.21043/jp.v12i2.4899.

Lee, T. T., \& Osman, K. (2012). Interactive Multimedia Module in the Learning of Electrochemistry: Effects on Students' Understanding and Motivation. Procedia - Social and Behavioral Sciences, 46. https://doi.org/10.1016/j.sbspro.2012.05.295.

Li, L. (2020). Education Supply Chain in the Era of Industry 4.0. Systems Research and Behavioral Science, 37(4), 579-592. https://doi.org/10.1002/sres.2702.

Linda, R., Herdini, Sulistya, I., \& Putra, T. P. (2018). Interactive E-Module Development through Chemistry Magazine on Kvisoft Flipbook Maker Application for Chemistry Learning in Second Semester at Second Grade Senior High School. Journal of Science Learning, 2(1), 21-25. https://doi.org/10.17509/jsl.v2i1.12933.

Liu, X., Kong, J., Jiang, M., \& Li, S. (2021). Interactive information Module for Person Re-Identification. Journal of Visual Communication and Image Representation, 75. https://doi.org/10.1016/j.jvcir.2021.103033.

Manurung, \& Panggabean. (2020). Improving Students' Thinking Ability In Physics Using Interactive Multimedia Based Problem Solving. Cakrawala Pendidikan, 39(2), 460-470. https://doi.org/10.21831/cp.v39i2.28205.

Mastroleo, N. R., Humm, L., Williams, C. M., \& Kiluk, B. D. (2020). Initial Testing of a Computer-Based Simulation Training Module to Support Clinicians' Acquisition of CBT Skills for Substance Use 
Disorder Treatment. Journal of Substance Abuse Treatment, 114. https://doi.org/10.1016/j.jsat.2020.108014.

Maunah, B. (2015). Implementasi Pendidikan Karakter dalam Pembentukan Kepribadian Holistik Siswa. Jurnal Pendidikan Karakter, 1. https://doi.org/10.21831/jpk.v0i1.8615.

Muhamad Nova. (2017). Character Education in Indonesia EFL Classroom Implementation and Obstacles. Jurnal Pendidikan Karakter, 7(2). https://doi.org/10.21831/jpk.v7i2.13650.

Neppala, P., Sherer, M. V., Larson, G., Bryant, A. K., Panjwani, N., Murphy, J. D., \& Gillespie, E. F. (2018). An Interactive Contouring Module Improves Engagement and Interest in Radiation Oncology Among Preclinical Medical Students: Results of A Randomized Trial. Practical Radiation Oncology, 8(4). https://doi.org/10.1016/j.prro.2018.01.001

Palunga, \& Marzuki. (2017). Peran Guru dalam Pengembangan Karakter Peserta Didik di Sekolah Menengah Pertama Negeri 2 Depok Sleman. Jurnal Pendidikan Karakter, 1(1). https://doi.org/10.21831/jpk.v7i1.20858.

Prastika, V. Y. A., Riyadi, R., \& Siswanto, S. (2021). Discovery and Core Learning Model toward Creative Thinking Viewed from Logical Mathematical Intelligence. Jurnal Aksioma, 10(1). https://doi.org/10.24127/ajpm.v10i1.3429.

Qumillaila, Susanti, B. H., \& Zulfiani, Z. (2017). Pengembangan Augmented Reality Versi Android sebagai Media Pembelajaran Sistem Ekskresi Manusia. Cakrawala Pendidikan, 34(1), 57-69. https://doi.org/10.21831/cp.v36i1.9786.

Rasmussen, E., Goddard, A. G., \& Bayer, D. K. (2020). Use ff Electronic Learning Modules Can Improve Medical Trainee Knowledge Regarding Anaphylaxis Diagnosis and Treatment. Annals of Allergy, Asthma \& Immunology, 124(3). https://doi.org/10.1016/j.anai.2019.12.018.

Resita, I., \& Ertikanto, C. (2018). Designing Electronic Module Based on Learning Content Development System in Fostering Students' Multi Representation Skills. Journal of Physics: Conference Series, 1022(1), 012025. https://doi.org/10.1088/1742-6596/1022/1/012025.

Rosikum, R. (2018). Pola Pendidikan Karakter Religius pada Anak melalui Peran Keluarga. Jurnal Kependidikan, 6(2). https://doi.org/10.24090/jk.v6i2.1910.

Sadimin Sadimin, Wahyu Hardyanto, \& Slamet, A. (2017). Developing an E-Module-Based Classroom Action Research Management Training Model for Teachers High School. International Journal of Education and Research, 5(2), 79-90. https://doi.org/10.15294/jed.v5i3.18123.

Sailer, M., Stadler, M., Schultz-Pernice, F., Franke, U., \& Schöffmann, C. (2021). Technology-Related Teaching Skills and Attitudes: Validation of a Scenario-Based Self-Assessment Instrument for Teachers. Computers in Human Behavior, 115. https://doi.org/10.1016/j.chb.2020.106625.

Seruni, R., Munawaroh, S., Kurniadewi, F., \& Nurjayadi, M. (2020). Implementation of E-Module Flip PDF Professional to Improve Students' Critical Thinking Skills through Problem Based Learning. Journal of Physics: Conference Series, 1521(4), 1-6. https://doi.org/10.1088/1742-6596/1521/4/042085.

Singh, B. (2019). Character Education in the 21'st Century. Journal of Social Studies (JSS), 15(1), 1-12. https://doi.org/10.21831/jss.v15i1.25226.

Soleimani, E., Ismail, K., \& Mustaffa, R. (2014). The Acceptance of Mobile Assisted Language Learning (MALL) among Post Graduate ESL Students in UKM. Procedia - Social and Behavioral Sciences, 118. https://doi.org/10.1016/j.sbspro.2014.02.062.

Sri Sulistiyawati, R. (2018). Pengaruh Media Pembelajaran Berbasis Video terhadap Hasil Belajar Siswa Sejarah Artikel: Influence of Video-Based Learning Media to Student Learning Outcomes. Cakrawala Jurnal Pendidikan, 12(1), 24-31.

Sugiyono. (2018). Metode Penelitian Pendidikan Pendekatan Kuantitatif, Kualitatif dan R\&D. Alfa Beta.

Susanti, N., Yennita, Y., \& Azhar, A. (2020). Development of Contextual Based Electronic Global Warming Modules Using Flipbook Applications as Physics Learning Media in High Schools. Journal of Educational Sciences, 4(3), 541. https://doi.org/10.31258/jes.4.3.p.541-559.

Syahroni, M. W., Dewi, N. R., \& Kasmui. (2016). The Effect of Using Digimon (Science Digital Module) with Scientific Approach at the Visualization of Students' Independence and Learning Results. Jurnal Pendidikan IPA Indonesia, 5(1), 116-122. https://doi.org/10.15294/jpii.v5i1.5800.

Tchen, P., Leung, L., Simpson, F., Kim-Sing, A., \& Pearson, M. L. (2018). Bridging the Gap: An Evaluation of Self-Paced Online Transition Modules for Advanced Pharmacy Practice Experience Students. Currents in Pharmacy Teaching and Learning, 10(10). https://doi.org/10.1016/j.cptl.2018.07.006.

Triwahyuningtyas, D., Ningtyas, A. S., \& Rahayu, S. (2020). The Problem-Based Learning E-Module of Planes Using Kvisoft Flipbook Maker for Elementary School Students. Jurnal Prima Edukasia, 8(2), 199-208. https://doi.org/10.21831/jpe.v8i2.34446. 